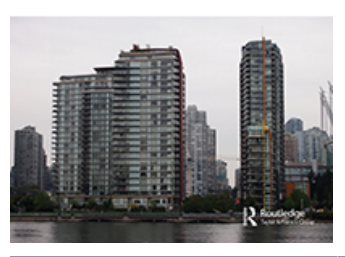

ISSN: 0272-3638 (Print) 1938-2847 (Online) Journal homepage: https://www.tandfonline.com/loi/rurb20

\title{
Housing privatization and the return of the state: changing governance in China
}

\section{Fulong Wu}

To cite this article: Fulong $\mathrm{Wu}(2018)$ Housing privatization and the return of the state: changing governance in China, Urban Geography, 39:8, 1177-1194, DOI: $10.1080 / 02723638.2018 .1440126$

To link to this article: https://doi.org/10.1080/02723638.2018.1440126
(2) 2018 The Author(s). Published by Informa UK Limited, trading as Taylor \& Francis Group.
曲 Published online: 02 Mar 2018.

Submit your article to this journal

Џlll Article views: 1106

View Crossmark data ־

Citing articles: 1 View citing articles 


\title{
Housing privatization and the return of the state: changing governance in China
}

\author{
Fulong Wu \\ Bartlett School of Planning, University College London, London, UK
}

\begin{abstract}
Housing privatization seems to suggest a process of state retreat. However, this is not always the case in China. This paper examines an estate that is mixed with work-unit housing and municipal public housing to understand its changing governance. It is intriguing to observe that the state has had to return to this neighborhood to strengthen its administration following housing privatization, because the attempt to transfer responsibility to commercial property management failed. The neighborhood governance, however, has transformed from one based on work-units to a government-funded administrative agency. The return of the state has been achieved through professional social workers, and it is struggling to operate, leading to the alienation and disempowerment of former state work-unit residents. The side effect of this approach to governance is that, through encouraging market provision and commercial operation which is not fully working, reciprocal activities are restrained. Since housing privatization, the neighborhood has deteriorated from a brand-new estate into an 'old and dilapidated neighborhood' in less than 25 years.
\end{abstract}

\section{ARTICLE HISTORY}

Received 10 January 2017

Accepted 31 January 2018

\section{KEYWORDS}

Governance; housing

privatization;

neighborhoods; work-unit

housing; China

\section{Introduction}

The neighborhood is an important spatial form to foster social bonding (Putnam, 2001). Despite the coming of an urban age, a small living space like a neighborhood cherished by everyone arguably still plays a role in place-making (Friedmann, 2010). Forrest and Kearns (2001) emphasize that the neighborhood is a key dimension for maintaining social cohesion. In the UK, the significance of the neighborhood was highlighted in area-based regeneration under New Labor (Kearns \& Parkinson, 2001) as well as in recent localism's support for the community. The significance of the neighborhood persists in urban policies (Kearns \& Forrest, 2000; Paddison, 2001). With the growing importance of flows of people, goods and information, and with greater mobility, territorialized social practices are crucial, as argued by van Kempen and Wissink (2014, p. 95), because "Neighborhoods continue to play a role in the actions and imaginations of people, neighborhood organizations, and government policies. People still live in neighborhoods, and government still tries to solve often severe social problems through neighborhood policies." Neighborhood-level social-spatial inequalities have significant impacts on social cohesion (Cassiers \& Kesteloot, 2012). 
The rise of private governance in the form of gated communities is a salient feature of changing neighborhood governance (Blakely \& Snyder, 1997). There are extensive studies of middle-class neighborhoods and gentrification (Lees, 2008). On the other hand, economic restructuring and a changing political economic environment have created acute pressures on working-class neighborhoods (Ward, Fagan, McDowell, Perrons, \& Ray, 2007). At the other extreme, territorial stigmatization strongly targeted specific neighborhoods and affected ethnically diverse communities in Britain (Slater \& Anderson, 2012), and social exclusion occured in poor neighborhoods (Musterd, Murie \& Kesteloot, 2006). Racial practices and stigmatization suppressed civic development in American ghettos (Wacquant, 2008). In the post-socialist economies, neoliberalism and market transition have transformed domestic and neighborhood lives (Smith \& Rochovska, 2007). Commodification seems to be a major process that affects neighborhood governance.

While there has been a burgeoning literature on urban China (Friedmann, 2005; Hsing, 2010; Logan, 2008; Ma, 2002) and neighborhood governance (Boland \& Zhu 2012; Bray, 2005, 2006; Read, 2000, 2012; Tomba, 2005, 2014; Wu, 2002), these studies paid more attention to the new forms of gated communities built under the housing market (Huang, 2006; Pow, 2009; Zhang, 2010) or informal urban villages (Wang, Wang, \& Wu, 2009; Wu, Zhang, \& Webster, 2013). The re-establishment of neighborhood governance through expanding the role of previous neighborhood organizations such as residents' committees is well documented (Read, 2000; Tomba, 2014; Wu, 2002). However, it is not entirely clear why housing privatization has not led to greater self-governance. How does the state manage to maintain control in work-unit housing areas where service provision has been largely privatized? The current literature emphasizes the state's desire to control or using new techniques to govern (e.g. Ong, 2007; Read, 2012; Tomba, 2014), while paying insufficient attention to contextual neighborhood changes. More importantly, the maintenance of the state's role is not contradictory with the deployment of market instruments $(\mathrm{Wu}, 2017 \mathrm{a})$ because the latter has left a vacuum of governance that requires state intervention. This paper will provide a more nuanced understanding of the implication of housing privatization for neighborhood governance, using a public housing area that consists of both work-unit and municipal housing as an example. While the specificity of the work-unit housing should be taken into account, the observation opens up the possibility to think about other neighborhoods in a similar way.

This study chose an ex-public housing neighborhood in Nanjing, which was jointly invested in and constructed by several state work-units in the mid-1980s, just before the introduction of the housing market and housing privatization. The Fifth Village (a pseudonym) is located on the edge of Nanjing. Because Nanjing was a relatively compact city, the distance from the neighborhood to the city center only takes about 30 minutes by bicycle. The area is now part of the city proper.

\section{Changing neighborhood governance in urban China}

In this section, the features of neighborhood governance prior to economic reform, the initiative to "build communities" under economic reform, and rising "private governance" are reviewed to identify research gaps. 


\section{The dominance of state work-units in urban governance prior to economic reform}

Under state socialism, state work-units (danwei) were the main organizers of neighborhood life (Bray, 2006; Friedmann, 2005, 2007; Whyte \& Parish, 1984; Wu, 2002). This created an organized dependence on the state, known as "communist neotraditionalism" (Walder, 1986), which replicated the traditional features of stable neighborhoods. The neighborhoods of municipal housing and work-unit compounds are different, because "[the work-unit community] is already part of a rational, futureoriented, differentiated, technological structure, and it has been quite effective in important modernization tasks. It is a community within modernity, within a division of labor - a transfigured community" (Womack, 1991, p. 330). This argument distinguishes two types of neighborhoods and their governance prior to economic reform: neighborhoods that relied on state work-units and neighborhoods that were based on informal neighborhood organizations that were still under the supervision of the state.

State work-units played a key role in housing provision and organized social lives (Logan, Fang, \& Zhang, 2010; Walder, 1986). The strong capacity of governance was in contrast to weaker governance in old neighborhoods which were more or less based on self-organization by residents' committees (ju wei hui) served by retired people and housewives (Read, 2000; Whyte \& Parish, 1984).

\section{The decline of work-units and "community construction" since the 1990s}

Market-oriented reform in the 1990s has created great impacts on neighborhood governance (Friedmann, 2005). Along with economic decentralization, Chinese cities have seen the influx of rural migrants and laid-off workers who are no longer attached to state work-units. These were private sector workers outside the traditional mechanism of social control, and thus it was an imperative to reconnect those outsiders with the state; this has been achieved through the top-down "community construction" initiative (Bray, 2006; Friedmann, 2005, 2007; Heberer \& Göbel, 2011; Read, 2000; Shi \& Cai, 2006; Shieh \& Friedmann, 2008; Wu, 2002).

The initiative of "community construction" arguably strengthened state control. Wong and Poon (2005) argue that the institution of the neighborhood has been transformed from "serving neighbors to recontrolling urban society." The policy aimed to recreate a close and intimate small space where social surveillance could be effectively achieved. In Shanghai, urban governance adopted a new model of two levels of government (municipality and district governments) and three levels of administration (adding the street office of government). Later the system was extended to include the fourth layer of residents' committees as the agent of local government (Wu, 2002). The development of residents' committees represents the extension of state governance into the neighborhood (Read, 2000).

\section{Rising property rights awareness in gated communities since the 2000s}

The retreat of the state from housing provision and the emergence of entrepreneurial governance have been arguably characterized as neoliberal urbanism ( $\mathrm{He} \& \mathrm{Wu}, 2009$; 
Walker \& Buck, 2007), echoing a process of "neoliberalization" (Harvey, 2005). The demise of danwei as an organizational form of urban governance is the major change (Bray, 2005; Huang, 2006; Logan et al., 2010; Wu, 2002). It is observed that traditional forms of social bonding are declining, showing up as less frequent neighborhood activities (Forrest \& Yip, 2007), while social networks grow beyond neighborhoods (Hazelzet \& Wissink, 2012).

There have been extensive studies on the emergence of new residential forms of "gated communities" in China (Huang, 2006; Pow, 2009; Zhang, 2010) and the rise of homeowners' associations in these new neighborhoods (Fu \& Lin, 2014; Read, 2003; Shi \& Cai, 2006; Tomba, 2005, 2014). Though social interaction at the neighborhood level has declined (Forrest \& Yip, 2007), middle-class housing estates retain strong place affection and attachment (Zhu, Breitung, \& Li, 2012) and strong awareness of their property rights (Tomba, 2005), perhaps due to shared identity and interest in property. Read (2012) studied the residents' committee as government sponsored network as a form of "administrative grassroots engagement" to embody governance and facilitate policing at the most local level. His research reveals the connection between the state and society within the neighborhood. Tomba (2014) highlights the importance of neighborhood as the place where residents' everyday lives are governed at a distance by the government. In other words, it is in the neighborhood that the state's authoritarian governance is achieved. Rather than seeing the trend towards more tightly controlled neighborhoods, Gui, Ma, and Mühlhahn (2009) suggest the emergence of increasingly fragmented neighborhood organizations. Neighborhood elections and new approaches to welfare delivery have been experimented with (Derleth \& Koldyk, 2004; Friedmann, 2011). Thus, the dichotomist state-society approach becomes inappropriate because a third realm, which is between the state and the market, has been created at the neighborhood level (Gui et al., 2009). However, Fu and Lin (2014) show that undeveloped social capital led to the lack of civic engagement and in turn made the homeowners' association a weak territorial organization.

From the above review, we can see that commodity housing development tends to enhance the awareness of property rights. Shared interests and identity may challenge the state and require more grassroots democracy (Cai \& Sheng, 2013; Fu \& Lin, 2014; Shi \& Cai, 2006; Shin, 2013). The question is then how does the state manage to continue to enforce its control even when facing strong property rights awareness? How does the process work in work-unit housing areas where property rights awareness is much weaker? We need to understand commodification, privatization and state-led "community building" as complementary processes to foster state hegemony.

\section{The context of the case and research methodology}

The Fifth Village is located not too far from the central areas but connection with the city is not very easy. The place was relatively isolated and confined by a river that was also used for sewer discharge, cutting off the roads to the city. Cyclists used the rugged riverbanks to travel to the city in the 1990s. The area was close to the docklands along the Yangtze River where manual workers lived. This was the edge of the city.

Before 1949 rural refugees concentrated in the area and built simple shacks. The place was gradually converted into shantytowns. In the 1980s the city of Nanjing 
decided to renew this area because it was visible from trains across the Yangtze River Bridge to the city (a deputy director of city planning bureau, July 2001). The area was also chosen because there were farm lands and vacant low lands. The population density was relatively low. The pressure to rehouse the original residents was lower.

In 1986 the urban redevelopment office launched this project to develop a large estate. The project rehoused relocated households from nearby old areas. Two workunits also bought six residential buildings for their staff. The total area was 8.2 hectares. The total building floor space was 104,000 square meters. The estate consisted of 35 residential buildings, one nursery, one primary school and some buildings for shops along the main road in 1987. In 2001, more buildings were added, totaling 52 buildings in the Fifth Village, accommodating 2,565 households and a population of 7,472 persons (the director of residents' committee, July 2002). About ten years after the estate was built, China initiated full-fledged housing commodification (Hsing, 2010; Logan, 2008), which had an immense impact on this public housing estate.

This study is based on the experience of living in this neighborhood from 1987 to 1991 and ethnographic observation from regular visits thereafter. In the period between 2001 and 2004, an initial investigation of neighborhood governance was done through semi-structured interviews of officers and directors of the neighborhood as well as residents living in the neighborhood, in response to the policy to promote "community construction" (Boland \& Zhu, 2012; Derleth \& Koldyk, 2004; Friedmann, 2011; Read, 2000; Shieh \& Friedmann, 2008; Tomba, 2014). In 2008, investigation focused on the sale of ex-public housing. The two major estate agents in the area and eight residents who became owners through privatization were interviewed. In 2014 interviews were conducted with the street offices of the government (which is also known as the "subdistrict” government (Derleth \& Koldyk, 2004)) and residents' committees. Overall, 21 unstructured and semi-structured interviews were conducted. Whenever possible, the interviews were triangulated through conversations with estate agents, residents, and neighborhood cadres. It must be emphasized that the semi-structured interviews were done through a more formal process with government and neighborhood officials compared with many informal conversations with the residents (which are not counted as interviews). Due to familiarity with the neighborhood and five years' living experience, triangulation of conversations has been possible. These interviews lasted over a long period of time because of the sustained research interest in micro-level state control. While less formally organized as a research project which tends to use crosssection method, I believe this "longitudinal" approach helps to reveal the long-term trend. Some data were collected from Nanjing Real Estate Market 2000, which provides some basic information about housing prices at the neighborhood level in 2000. This is now supplemented by more detailed housing market data from 2014. As the study does not aim to provide detailed information about the housing market, no systematic effort was spent comparing housing prices with other areas.

\section{Housing privatization and the retreat of the state}

The most significant implication of housing privatization is changing property management. Responsibility has been transferred from individual work-units that owned housing to the property management company that was recruited to take charge of 
property and estate maintenance. This was justified by the fact that through housing privatization the sitting tenants of public housing have become homeowners. However, since housing privatization property maintenance in this estate has faced difficulties. For example, a sewer was blocked because some residents poured rubbish into it during housing refurbishment (a homeowner, August 2008). The estate department of workplaces was no longer responsible for dredging because the housing had been privatized. On the other hand, the residents failed to coordinate themselves because not every household was affected by this problem at the same time. Thus, residents had to ask a private plumber to drill a hole in the external wall to set up a simple duct outside the building when the problem arose.

The most salient feature is that the state withdrew from "neighborhood services," a term virtually unknown until the early 1990s. Before that time services at the neighborhood level were confined to assistance provided to the poor families that received welfare benefits from the civil affairs department. These mainly included disaster relief and social assistance to the handicapped and the elderly (Solinger \& Hu, 2011; Womack, 1991). For most residents, services were provided through their workplaces as occupational benefits. In the 1950s, street offices began to organize housewives and self-employed people into street handicraft workshops and small factories. This laid down the foundation of the "street collective economy." The development of the collective economy helped provide employment to those who were unable to be formally recruited by state-owned enterprises. In the 1980s, because of the return of urban youth from the countryside, unemployment pressure increased. Street offices organized various street services such as TV repairs, barbers, and housing maintenance to absorb the returnees from the countryside (an officer in the residents' committee, July 2002). As a result, neighborhood services became an important sector of the collective economy, but they were operated on a small scale, similar to social enterprises.

The major change came in 1992 when the State Council classified neighborhood services as tertiary industry. This opened the door to the commodification of public services at the grassroots. In the 1990s, the decision to commercialize neighborhood services led to the proliferation of businesses run by street offices. For example, in the Fifth Village, the street office owned the premises of small shops and convenience stores along the main road and leased them to private businesses. The income drawn from the rental was used to subsidize the budget of the street office (a street officer, July 2002). Similarly, the residents' committee maintained a local community center and managed some simple one-story shacks to accommodate rural migrants. These business activities generated income to subsidize the operational costs of the residents' committee. In the 1990s, residents' committees managed to tap into market resources to provide paid services to residents. Shanghai even adopted a tax rebate policy to stimulate the development of a street economy (a street office manager, Shanghai, August 2002). Under the policy, street offices enthusiastically supported the registration of private business in their territories for the rebate of value added tax.

At the very beginning of promoting the privatization of neighborhood services, there were debates about whether neighborhood services were public goods delivery or a business of the service industry: "We believe the policies were contradictory; the State Council decision was not the same as the notice sent by the Ministry of Civil Affairs. The latter believed service is for public goods. Now the neighborhood service is 'one 
servant for two masters.' That was really confusing, and the purpose of developing neighborhood services was quite different!” (a civil affairs official, August 2002).

The premises along the main road of the Fifth Village were sold to private companies around 2000. The street office no longer collected rentals from these properties. In the 2000s, the street office managed to use the roads inside the neighborhood for parking trucks and other vehicles to earn parking fees. After 2008 the residents' committee no longer managed parking spaces because of the shortage of parking space and potential liability. The collection of parking fees may also create liability complications. In the Fifth Village, the street office director mentioned an incident where two drivers fought for a parking space, resulting in one driver being seriously injured. "[The other driver] had to pay a compensation of 80,000 yuan to get the settlement. This would bring us a lot of troubles if we had collected parking fees!" (director of residents' committee, November 2014). The street office and residents' committee played the role of arbitrator rather than stakeholder. Commercial activities have now been stripped from the operations of the street office and residents' committee. The street office is now entirely dependent upon the budget assigned from the district government, and in turn the residents' committee operates on specifically allocated funds for administrative tasks.

In the Fifth Village, there used to be some one-storey houses and shacks managed by the residents' committee for renting to rural migrants. But nearby commodity housing development projects demolished these premises. Originally, the neighborhood controlled a grocery market and collected a maintenance fee. But since the street market was moved into a formal indoor market, the residents' committee can no longer collect the fee. In some old neighborhoods, the residents' committee undertook small services such as milk and newspaper deliveries, or introducing nannies and domestic helpers. But all these services have been fully commercialized. For example, there are special domestic helper centers. In the Fifth Village, commercially operated sports and recreational activities are organized by private businesses. Some outdoor sports facilities were invested in by the street office of the government under specific funding and opened to the public.

The insulation of the residents' committee from market operation is due to two considerations. First, involvement in the market proved to create many irregularities and even corruption because the director acted as both cadre and businessperson. ${ }^{1}$ Second, regulation prevented the residents' committee from evolving into an independent "self-organized mass organization" through gaining independent financial sources. ${ }^{2}$ In this direction, residents' committees might become charities or non-government organizations (NGOs) with their own business accounts. This direction of change was regarded as undesirable by the state because it would weaken state control over neighborhood governance. The policy of separating business and residents' committees has transformed the nature of the residents' committee from an organization that comprehensively deals with neighborhood affairs into a public administration agency.

\section{The imperative for an enhanced state presence in neighborhood governance}

In this section, I will explain why privatization is not a one-way trajectory. The failure of commercial property management in many work-unit housing areas creates an imperative for the state to return in a more territorialized form. In the period of 
socialism, the street office together with a neighborhood organization played a complementary role in social welfare and service provision. Their main targets were residents without workplace affiliation and the recipients of benefits from the civil affairs department, including the handicapped, widows, the elderly without children, veterans, and their families, while the majority of the population depended upon their workplaces for social services (Solinger \& Hu, 2011). Neighborhood management remained underdeveloped until the introduction of privatization. Treating neighborhood management as paid services created a chance for developing property services through the market. Along with the unfolding of full-fledged privatization, public spaces have been privatized into commercial premises, and residents' committees no longer provide services that can be delivered commercially. Property management companies were introduced to take over some functions.

While work-unit housing has been privatized, the road to a self-governed neighborhood has not been smooth. It is difficult to recruit a property management company in this work-unit housing area because the residents could not afford the maintenance fees or were reluctant to pay them (a street property service manager, November 2014). After privatization, "We tried very hard to find a property management company [to look after the estate], but you know the maintenance cost is very high" (director of street office, November 2014). Of 47 old and dilapidated residential districts in the territory of the street office, only eight are managed by property management companies, only one is formally managed by the homeowners' association, and about 27 residential estates are managed directly by the street office. The remaining 11 neighborhoods were left to the residents themselves, which basically means a lack of maintenance (street office director, November 2014). Because of the difficulty of collecting property management fees, the property management company that took charge of the Fifth Village abruptly withdrew its service, leaving the neighborhood in a state of limbo (director of residents' committee, November 2014). After property management companies abandoned their role, the street office had to ask the residents' committee to do what it could - according to the director, "Our ability is at most to do some small fixes and repairs" (the director, November 2014). As early as 2000, there were many signs of deterioration, for example, broken windows, under-maintained bushes, and sewage blockages.

The failure of commercial operation imposes significant demands for the state to maintain its role in neighborhood governance. In contrast to urban villages that draw income from the assets under village collectives (Po, 2008), the work-unit housing neighborhood has limited resources and has to depend on government funding. Moreover, as a modern public housing estate, the Fifth Village does not have many commercial establishments in its jurisdiction area. Therefore, the neighborhood has been constrained by resources to support neighborhood services. Following housing privatization, the residents' committee is no longer supported by the work units and so has to approach those enterprises within the area for "donations." The director of the residents' committee described how they were just like a "Buddhist monk begging for alms". For services that can possibly be privatized, residents have to pay for themselves. "We don't have to do anything. In fact, we can do nothing. All we could do is to fix small problems here and there" (a residents' committee officer, November 2014). When asked who would pay for maintaining trees and grass in the neighborhood, the officer in the street office was anxious: "This is the area where you spend money but don't see where it has gone. Trees, 
bushes and grass grow every year, and so you have to pay for them every year. We just spent 200,000 yuan on the maintenance of green spaces. Whenever possible, we just had to convert grassland into hard surfaces. We had no choice" (a street property management officer, November 2014). The continuing pressure on the residents' committee means it has to be professionalized through state funding.

\section{The return of the state as a territorialized form of governance}

\section{Increasing size of residents' committee and its professionalization}

Housing commodification has led to greater residential mobility in urban China. Private sector workers are no longer affiliated to a state workplace that operates as an institution for social management (Walder, 1986). The influx of rural migrants has increased residential diversity. The bankruptcy of state-owned enterprises led to millions of laid-off workers who were transferred from workplaces to the places where they live (Solinger \& Hu, 2011). Residential relocation created the problem of the mismatch of the location of household registration and the actual place of living. In short, urban China in the aftermath of commodification has seen an unprecedented tendency towards ungovernable spaces $(\mathrm{Wu}, 2002)$. Confronted with an increasingly fluid society, the state strived to consolidate neighborhood governance (Read, 2000; Tomba, 2014). Moreover, there has also been an increasing practical need to deliver social assistance to those who are not within the state enterprise system. The residents' committee thus has been chosen as a territorialized form of governance.

Previously in this large residential area, there were three residents' committees served by retired people and housewives. In 2000, they were dismissed, and the three residents' committees were merged into a single residents' committee (a residents' committee officer, July 2002), which later is known as shequ. The new residents' committee is served by professional social workers recruited formally by the street office of the government. The cadres came from other places. Although in theory local residents are also eligible to serve the residents' committee, in practice it is difficult find professional social workers in the same neighborhood. Officials were appointed based on education attainment and qualification, regardless of whether they came from local communities. The residents' committee has a proper office with desks and filing cabinets. It has become a de facto government agency performing administrative duties. Regular administrative tasks include delivery of social assistance, family planning, neighborhood education, health and hygiene campaigns, women's affairs, organizing neighborhood cultural and sport activities, mediation of neighborhood and domestic conflicts, and maintenance of public space.

The residents' committee plays an important role in neighborhood governance. For example, in this neighborhood, the cadres should pay home visits to a family that had lost a member to explain funeral and interment procedures (a street officer, November 2014). The office is in charge of allocation of minimum livelihood support and other welfare benefits from the civil affairs department (Solinger \& $\mathrm{Hu}, 2011$ ). The residents' committee also tries to maintain contacts with poor families in the neighborhood. In the 2000s, the residents' committee also helped to verify rental spaces for rural migrants and checked their family planning measures. Other tasks in more informal 
peri-urban villages include the creation of new addresses for rental properties so that migrants living in these properties could be "geo-located" (a district planning officer, August 2010). In some informal urban areas, new address plates were created for the rooms accommodating rural migrants.

The major change for the residents' committee is the bureaucratization of the organization. Initially in 1954 the organizational law of residents' committees stipulated the residents' committee as a "self-organized mass organization." Subsequently in 1989 the law defined it as a "resident self-managed, self-educated, and self-served local mass self-organized organization" (Womack, 1991), though in reality the residents' committee is always guided by the government and is thus different from "grassroots organizations" in the West. The original size of the residents' committee was relatively modest. The residents' committees in the Fifth Village were each in charge of 100 to 700 households and staffed by five to nine people, mainly from the neighborhood. In 2001, it managed 7,472 residents (a residents' committee officer, July 2002). But in 2014, the Fifth Village residents' committee needed to serve more than 11,000 residents, about ten percent of whom were rural migrants (director of residents' committee, November 2014).

\section{The separation between social management and commercial services}

The budget of the residents' committee is allocated by the street office of the government. Compared with the huge demand for assistance and management, the budget has been always seen as inadequate. In 2002, the street office only allocated 180 Yuan per month, which was barely enough for telephone bills and office stationery. The director of the Fifth Village residents' committee complained, "We don't have enough funding. We often have to go back to our original workplaces to make photocopies of administrative forms" (director of residents' committee, July 2002). In 2014, the annual budget increased to 50,000 Yuan, but this is still short of covering the basic operational costs (director of residents' committee, November 2014), although when asked about the use of stationery, the director said that it could be simply obtained from the office.

Being a cadre in a residents' committee is hard work. They often have to work overtime, especially when the city organizes mega events. During the Youth Olympic Games in the summer of 2014, the cadres of residents' committees had to carry out security checks and patrol the neighborhood to ensure there would be no social incidents. For young professional social workers, "The pay is not high enough compared with private sector jobs; young social workers also keep an eye on other possibilities" (director of residents' committee, November 2014). Recently, six social workers resigned from the residential estates under the street office. In the Fifth Village: "We just lost two social workers. We are unable to fill these posts because the district government has not started its formal recruitment" (ibid).

Now, different from the early stage of market reform, the residents' committee is forbidden to tap into market resources and has turned into a purely administrative agency. For example, residents' committees are no longer allowed to operate housing rentals or maintenance charges. Parking charges from spaces inside the neighborhood are submitted directly to the property management company. In fact, all paid services have been transferred to the property management company. This regulation reduced 
irregularities in the residents' committee but at the same time constrained its resources. As a neighborhood organization, the residents' committee has to cope with requests from various government departments. However, its funding mode reflects the nature of the residents' committee as an administrative agency. The street office allocates the basic budget covering the salaries of cadres. Other government departments can also ask the residents' committee as the "agent on the ground" to carry out specific tasks. But they have to assign specific budget to cover these costs. For example, when the Bureau of Statistics needs to organize a survey of urban livelihoods, it asks the residents' committee to contact residents in the neighborhood to book-keep their daily spending. Then the residents' committee receives a specific fund for handling the accounts of surveyed households. This practice of budget allocation on the basis of specific tasks helps to maintain the residents' committee as the agent of the government.

\section{The return of the state to an enhanced neighborhood governance}

The original rationale of consolidating neighborhood governance in the aftermath of privatization was to re-create a territorial form of social relations, resembling the environment of the workplace where officials were familiar with their employees and thus provided effective management. However, as can be seen from the Fifth Village, it is not easy to institutionalize the residents' committee in the same way as state workunits, because in this work-unit housing estate there is a severe resource constraint. To increase administration capacities, the street office of the government has to merge smaller residents' committees into a large residential community (shequ) organization and professionalize the operation of shequ. The new enlarged residents' committee has been professionalized.

However, the reform of neighborhood governance to achieve economies of scale comes at the cost of declining territorial social relations, because the consolidated residents' committee serves a very large territory and its officials are appointed from other places. The residents' committee is a non-democratically elected body which is not allowed to collect fees for its services to the neighborhood. It carries out purely administrative tasks assigned by the government. Many amalgamated residents' committees are too large for residents to know them personally. Unfamiliarity with the residents' committees has led to declining reciprocal social capital. In this peri-urban neighborhood, a series of privatization movements (in housing and neighborhood services) has not created a homeowners' association, as in middle-class commodity housing neighborhoods (Read, 2000, 2012; Tomba, 2005, 2014; Zhang, 2010). When asked about the possibility of setting up a homeowners' association, a resident replied (August 2008): "You mean us? Yes, I think I am an owner but I don't know what the homeowners' association is for. I hope this is not another way of collecting money!" Up to 2015, there was still no sign of setting up a homeowners' association, as the issue was deemed less relevant to this former work-unit housing area. In contrast to the newer middle class, the homeowners of previous work-unit housing do not feel a strong sense of ownership or property rights. They recognize the ownership right of their properties. But in terms of housing management, because of the low affordability constraint, they do not understand that their ownership could extend their control over the 
neighborhood governance. In contrast, they are aware of the possibility of an increasing financial burden, as the government now requires them to look after their property management through commercial services.

\section{Implications for neighborhood governance: alienation and disempowerment}

As a legacy of the centrally planned economy, ordinary residents in China were not involved in decision-making on urban development. Despite strong bonding in workunit living quarters, residents did not participate in neighborhood management. The residents, as state employees, relied on the estate department of their workplaces to carry out property maintenance. For municipal housing tenants, the Bureau of Housing Management was in charge of property maintenance. If work-unit housing tenants or municipal public housing tenants were not satisfied with the service, the residents had to resort to their employer or public housing management section. In the Fifth Village, the workplace appointed an officer of neighborhood affairs to liaise with the neighborhood. "If we have any repairs, we just ask our danwei [work-units]; the estate belonged to the danwei anyway. Why should we contact the residents' committee? They would not do the work for us" (a resident, July 2002). The residents thus had little chance to participate in neighborhood activity.

In newer housing estates, particularly those developed in suburban areas, homeowners are becoming more active in neighborhood governance. Housing commodification has created stronger awareness of property rights (Shin, 2013; Tomba, 2005). Residents set up homeowners' associations to represent their interests (Fu \& Lin, 2014). The homeowners' associations may then decide on the appointment of property management companies. In these gated communities, the rise of homeowners' associations has challenged the authority of the residents' committees (Pow, 2009; Read, 2012). The efforts of the government to strengthen the role of residents' committees in newer and gated housing estates is resisted by homeowners. For better-off residents, moving into a new commodity housing estate provides privacy (Pow, 2009; Zhang, 2010). Some homeowners believe that privacy gives them the freedom to be away from the social surveillance of residents' committees in public housing neighborhoods. In these newer housing estates, because the property management company is able to collect maintenance fees, these estates are generally well maintained and even secured with private security guards. The management service provided by the property management company reduces the workload of the residents' committees in commodity housing estates.

However, this was not the case in work-unit housing areas. In the Fifth Village, there was a sense of alienation among residents. Despite living in close proximity, there was very little interaction between work-unit residents and original residents. Physically, the work-unit housing was still fenced off in a mini-compound within the residential area. Although the flats were privatized, some work-unit staff still lived there. While in subsequent years, some owners in the work-unit compound sold their flats to the new comers outside the work-units, the division between those who lived inside and outside the compounds can still be seen. The residents lived in different worlds, like one retired teacher who had plenty of spare time but claimed that, "I cannot imagine playing mahjong with them at the road side!" (interview with a resident, July 2002). 
When a female migrant was asked by the neighborhood official to show her marriage certificate (for contraceptive measures), she looked puzzled and said, "But we have been married for over eighteen years!" (July 2002). In this larger professionally run neighborhood administrative agency, nobody actually knew her well enough to provide evidence of her marriage.

The decline of neighborhood interaction is also due to housing commodification (Forrest \& Yip, 2007; Hazelzet \& Wissink, 2012). The sale of housing to sitting tenants has led to the retreat of workplaces in housing provision and property management, which means that residents now have to rely on themselves for property maintenance. They do not need to ask neighbors or colleagues in the work-units to help with their property maintenance. The size of the estate and the professionalization and formalization of neighborhood governance lead to reduced familiarity and the weakening of social relations. Now, housing management is formally outside the remit of the residents' committee. There is no reason for residents to ask for help from the residents' committee.

It has been difficult to set up voluntary organizations to help maintain public space and organize neighborhood activities. The loss of neighborhood and reciprocal help has not been compensated by the introduction of commercial property management, because the property management company later abandoned its service, which is not usual in similar public housing areas.

The privatization of work-unit housing has increased spatial mobility. Better off residents moved out to other commodity housing areas. The creation of a rental stock, although limited, has attracted private sector tenants. Rural migrants have come to this neighborhood. Initially in the 2000s, the residents' committee maintained a stock of rental housing for rural migrants and helped to verify the status of rural migrants before they could rent a property in the neighborhood. Since the mid-2000s property owners have begun to manage their own properties or asked estate agencies to negotiate with migrant renters. Migrants are registered with the local police station and are no longer managed by the residents' committee except for the issue of family planning. Female migrants may be contacted by the residents' committee for assistance for contraception measures: "We also offer free health check-up to women" (director of residents' committee, November 2014). Despite this service, migrant tenants do not have much contact with the neighborhood agency.

Through professionalizing neighborhood social management, the state strengthened neighborhood governance. At the same time, the state tried to incorporate voluntarism into its formal structure of governance. But it is difficult to mobilize residents into this formal governance structure. The director of the street office blamed the low quality (suzhi) of residents in this neighborhood: "It is difficult to reach consensus here. It is fine to organize singing and dancing activities. But nobody really contributes to neighborhood affairs. To be honest, there are more people joining in the fun but fewer do the work" (street office director, November 2014). However, to residents, "We have to make a living first. I am not claiming a low-income benefit (dibao), and why should I be an activist" (a resident, August 2008). "If there is a problem [with my apartment], I would try to find a company myself. If we have some problem in this neighborhood, we don't have money to sort it out. I doubt the residents' committee have the money" (a resident, August 2008). "I have nothing to do with neighborhood 
officials. I am a law-abiding person, anyway. I am just selling vegetables here in this market. But the locals are quite friendly" (a temporary resident, August 2008). Observed from this work-unit housing area, the feelings of alienation and disempowerment go beyond the factors of the physical design of modern residential spaces and higher residential mobility. It is a side effect of formalized and professionalized neighborhood governance.

\section{Conclusion}

This paper examines an ordinary public housing area built with work-unit housing and municipal housing just before the introduction of the housing market and housing privatization. The Fifth Village in Nanjing was invested in and developed by multiple state work-units. The housing was allocated to their employees as public housing. However, the neighborhood has changed from a brand-new estate to an "old and dilapidated neighborhood" over about 25 years. After housing privatization, the state work-units retreated from property management and related neighborhood services. Further, along with the privatization of neighborhood premises into commercial operation, the residents' committee - a neighborhood organization originally supported by volunteers, housewives and retired people under the supervision of the street-level state agency (the street office) - streamlined its function and has now become solely reliant on government funding, staffed with salaried professional social workers. Surprisingly, in the work-unit housing area, privatization does not empower residents into more active neighborhood self-governance. The transfer of property management to the commercial management company failed because of the low affordability of residents, creating an imperative for the state to return to a prominent presence in neighborhood governance, while at the same time imposing a heavy burden for its operation. However, the new form of governance is different from the comprehensive approach provided by state work-units. It is a more territorialized form of state agency operating at the neighborhood level. Whenever possible, the state agency emphasizes the use of market instruments and market operations. The co-existence of a professionalized and "bureaucratic" (in the sense of formality) agency and commercial services provided by various companies seriously discourages the development of reciprocal neighborhood activities. Alienation and disempowerment are the side effects of privatized and formalized neighborhood governance. While the narrative of neoliberalism would expect the state's retreat in the aftermath of mass housing privatization, there is now a welldocumented trend of consolidated state presence in China's governance (Friedmann, 2011; Read, 2000, 2012; Tomba, 2014; Wu, 2002, 2017a). However, the operational mechanism is not entirely known, particularly at the neighborhood level. The accounts of commodification and the continuation of state control seem to describe different aspects of urban transformation in urban China.

How are these two contradictory processes of privatization and enhanced state roles intertwined in actual neighborhood governance? In contrast to simply juxtaposing them in concepts such as "neoliberal authoritarianism" (Harvey, 2005), this paper attempts to describe how they are actually operating together through a "coherent" process of governing the Chinese urban neighborhood. Rethinking the concept of the "neoliberal city," an 
earlier attempt has been made to relate China's development model and governance approach (Wu, 2017b), but here I provide a close-up look at the neighborhood level.

Housing privatization helped the state work-units retreat from property management. Property management companies were asked to take over the role. But low income households could not afford this market form of service provision. This could mean an opportunity to develop reciprocal activities, which would enhance selfgovernance capacity. Perhaps residents had low expectations or were not unhappy with services in their neighborhood. But in reality, they witnessed the deterioration of their neighborhood. They might be helpless because of the lack of self-governance tradition under what Harvey (2005) described as the "authoritarianism." But what is found here is not the lingering authoritarianism. From the microscopic perspective, the paper focuses on the mechanism through which the deployment of market instrument has reduced neighborhood self-governance and in turn maintain "planning centrality" $(\mathrm{Wu}, 2017 \mathrm{a})$. The state required neighborhood services to take a commercial form. But the vacuum left by privatization has not been filled by private management or homeowners themselves, because of either low affordability or distrust of private companies even if the residents could afford them. The supposedly self-organized residents' committee is insulated from tapping into market resources and has been formalized through exclusive government funding. This vacuum left by privatization has "necessarily" been filled by the professionalization of neighborhood organizations.

From everyday neighborhood lives, we begin to understand the erosion of solidarity in the working-class neighborhood in a post-socialism context (Stenning, 2005). The underdevelopment of neighborhood self-governance is not simply state restriction but also more importantly the prevailing market approach over reciprocal relations in the context of fading neighborhood resources. All resources available to the neighborhood have been commoditized. As a result, housing privatization does not reduce residents' dependence on the state, but rather creates an imperative for the state to return to an enhanced governance.

\section{Notes}

1. This was the concern raised both in an interview with a street officer in 2004 and ten years later in 2014 by with another officer.

2. This is the conclusion inferred by this study, because our interviewees constantly mentioned the importance of "financial independence," suggesting that "we surely could have done more at our wish if we had our own source of money" (a street officer, November 2014).

\section{Acknowledgment}

I wish to thank Professor Xigang Zhu for helping with interviews in 2014.

\section{Disclosure statement}

No potential conflict of interest was reported by the author. 


\section{Funding}

This work was supported by the UK Economic and Social Research Council (ESRC)/Department for International Development (DFID) projects [ES/N015185/1, ES/P003435/1].

\section{References}

Blakely, Edward J., \& Snyder, Mary Gail. (1997). Fortress America: Gated communities in the United States. Washington, DC: Brookings Institution Press.

Boland, Alana, \& Zhu, Jiangang. (2012). Public participation in China's green communities: Mobilizing memories and structuring incentives. Geoforum, 43(1), 147-157.

Bray, David. (2005). Social space and governance in urban China: The danwei system from origins to reform. Stanford: Stanford University Press.

Bray, David. (2006). Building 'community': New strategies of governance in urban China. Economy and Society, 35(4), 530-549.

Cai, Yongshun, \& Sheng, Zhiming. (2013). Homeowners' activism in Beijing: Leaders with mixed motivations. The China Quarterly, 215, 513-532.

Cassiers, Tim, \& Kesteloot, Christian. (2012). Socio-spatial inequalities and social cohesion in European cities. Urban Studies, 49(9), 1909-1924.

Derleth, James, \& Koldyk, Daniel R. (2004). The Shequ experiment: Grassroots political reform in urban China. Journal of Contemporary China, 13(4), 747-777.

Forrest, Ray, \& Kearns, Ade. (2001). Social cohesion, social capital and the neighborhood. Urban Studies, 38(12), 2125-2143.

Forrest, Ray, \& Yip, Ngai-ming. (2007). Neighborhood and neighboring in contemporary Guangzhou. Journal of Contemporary China, 16(50), 47-64.

Friedmann, John. (2005). China's urban transition. Minneapolis: University of Minnesota Press.

Friedmann, John. (2007). Reflection on place and place-making in the cities of China. International Journal of Urban and Regional Research, 31(2), 257-279.

Friedmann, John. (2010). Place and place-making in cities: A global perspective. Planning Theory and Practice, 11(2), 149-165.

Friedmann, John. (2011). Invisible architecture: Neighborhood governance in China's cities. In Gary Bridge \& Sophie Watson (Eds.), The new Blackwell companion to the city (pp. 690-700). Oxford: Wiley-Blackwell.

Fu, Qiang, \& Lin, Nan. (2014). The weaknesses of civic territorial organizations: Civic engagement and homeowners associations in urban China. International Journal of Urban and Regional Research, 38(6), 2309-2327.

Gui, Yong, Ma, Weihong, \& Mühlhahn, Klaus. (2009). Grassroots transformation in contemporary China. Journal of Contemporary Asia, 39(3), 400-423.

Harvey, David. (2005). A brief history of neoliberalism. Oxford: Oxford University Press.

Hazelzet, Arjan, \& Wissink, Bart. (2012). Neighborhoods, social networks, and trust in post-reform China: The case of Guangzhou. Urban Geography, 33(2), 204-220.

He, Shenjing, \& Wu, Fulong. (2009). China's emerging neoliberal urbanism: Perspectives from urban redevelopment. Antipode, 41(2), 282-304.

Heberer, Thomas, \& Göbel, Christian. (2011). The politics of community building in urban China. London: Routledge.

Hsing, You-tien. (2010). The great urban transformation: Politics of land and property in China. Oxford: Oxford University Press.

Huang, Youqin. (2006). Collectivism, political control, and gating in Chinese cities. Urban Geography, 27(6), 507-525.

Kearns, Ade, \& Forrest, Ray. (2000). Social cohesion and multilevel urban governance. Urban Studies, 37(5-6), 995-1017.

Kearns, Ade, \& Parkinson, Michael. (2001). The significance of neighborhood. Urban Studies, 38 (12), 2103-2110. 
Lees, Loretta. (2008). Gentrification and social mixing: Towards an inclusive urban renaissance? Urban Studies, 45(12), 2449-2470.

Logan, John (Ed.). (2008). Urban China in transition. Oxford: Blackwell.

Logan, John, Fang, Yiping, \& Zhang, Zhanxin. (2010). The winners in China's urban housing reform. Housing Studies, 25(1), 101-117.

Ma, Laurence. J. C. (2002). Urban transformation in China, 1949-2000: A review and research agenda. Environment and Planning A, 33(9), 1545-1569.

Musterd, Sako, Murie, Alan, \& Kesteloot, Christian (Eds.). (2006). Neighborhoods of poverty: Urban social exclusion and integration in Europe. Basingstoke: Palgrave Macmillan.

Ong, Aihwa. (2007). Neoliberalism as a mobile technology. Transactions of the Institute of British Geographers, 32(1), 3-8.

Paddison, Ronan. (2001). Communities in the city. In Ronan Paddison (Ed.), Handbook of urban studies (pp. 194-205). London: Sage.

Po, Lanchih. (2008). Redefining rural collectives in China: Land conversion and the emergence of rural shareholding co-operatives. Urban Studies, 45(8), 1603-1623.

Pow, Choon-Piew. (2009). Gated communities in China: Class, privilege and the moral politics of the good life. Abingdon: Routledge.

Putnam, Robert. D. (2001). Bowling alone: The collapse and revival of American community. New York: Simon and Shuster.

Read, Benjamin. (2000). Revitalizing the state's urban 'nerve tips'. The China Quarterly, 163, 806-820.

Read, Benjamin. (2003). Democratizing the neighborhood? new private housing and home-owner self-organization in urban China. The China Journal, 49(1), 31-59.

Read, Benjamin. (2012). Roots of the state: Neighborhood organization and social networks in Beijing and Taipei. Stanford, CA: Stanford University Press.

Shi, Fayong, \& Cai, Yongshun. (2006). Disaggregating the state: Networks and collective resistance in Shanghai. The China Quarterly, 186, 314-332.

Shieh, Leslie, \& Friedmann, John. (2008). Restructuring urban governance: Community construction in contemporary China. City, 12(2), 183-195.

Shin, Hyun Bang. (2013). The right to the city and critical reflections on China's property rights activism. Antipode, 45(5), 1167-1189.

Slater, Tom, \& Anderson, Ntsiki. (2012). The reputational ghetto: Territorial stigmatisation in St Paul's, Bristol. Transactions of the Institute of British Geographers, 37(4), 530-546.

Smith, Adrian, \& Rochovska, Alena. (2007). Domesticating neo-liberalism: Everyday lives and the geographies of post-socialist transformations. Geoforum, 38(6), 1163-1178.

Solinger, Dorothy J., \& Hu, Yiyang. (2011). Welfare, wealth and poverty in urban China: The dibao and its differential disbursement. The China Quarterly, 211, 741-764.

Stenning, Alison. (2005). Post-socialism and the changing geographies of the everyday in Poland. Transactions of the Institute of British Geographers, 30(1), 113-127.

Tomba, Luigi. (2005). Residential space and collective interest formation in Beijing's housing disputes. The China Quarterly, 184, 934-951.

Tomba, Luigi. (2014). The government next door: Neighborhood politics in urban China. Ithaca: Cornell University Press.

van Kempen, Ronald, \& Wissink, Bart. (2014). Between places and flows: Towards a new agenda for neighborhood research in an age of mobility. Geografiska Annaler Series B-Human Geography, 96(2), 95-108.

Wacquant, Loic. (2008). Urban outcasts: A comparative sociology of advanced marginality. Cambridge: Polity Press.

Walder, Andrew. G. (1986). Communist neo-traditionalism: Work and authority in Chinese industry. Berkeley, CA: University of California Press.

Walker, Richard, \& Buck, Daniel. (2007). The Chinese road: Cities in the transition to capitalism. New Left Review, 46, 39-46. 
Wang, Ya Ping, Wang, Yanglin, \& Wu, Jiansheng. (2009). Urbanization and informal development in China: Urban villages in Shenzhen. International Journal of Urban and Regional Research, 33(4), 957-973.

Ward, Kevin, Fagan, Colette, McDowell, Linda, Perrons, Diane, \& Ray, Kath. (2007). Living and working in urban working class communities. Geoforum, 38(2), 312-325.

Whyte, Martin King, \& Parish, William L. (1984). Urban life in contemporary China. Chicago, IL: University of Chicago Press.

Womack, Brantly. (1991). Transfigured community: Neo-traditionalism and work unit socialism in China. The China Quarterly, 136, 313-332.

Wong, Linda, \& Poon, Bernard. (2005). From serving neighbors to recontrolling urban society. China Information, XIX(3), 413-442.

$\mathrm{Wu}$, Fulong. (2002). China's changing urban governance in the transition towards a more market-oriented economy. Urban Studies, 39(7), 1071-1093.

$\mathrm{Wu}$, Fulong. (2017a). Planning centrality, market instruments: Governing Chinese urban transformation under state entrepreneurialism. Urban Studies, (on-line), 1-16.

Wu, Fulong. (2017b). State entrepreneurialism in urban China. In Gilles Pinson \& Christelle Morel Journel (Eds.), Debating the neoliberal city (pp. 153-173). Abingdon: Routledge.

$\mathrm{Wu}$, Fulong, Zhang, Fangzhu, \& Webster, Chris. (2013). Informality and the development and demolition of urban villages in the Chinese peri-urban area. Urban Studies, 50(10), 1919-1934.

Zhang, Li. (2010). search of paradise: Middle-class living in a Chinese metropolis. Ithaca, NY: Cornell University Press.

Zhu, Yushu, Breitung, Werner, \& Li, Si-Ming. (2012). The changing meaning of neighborhood attachment in Chinese commodity housing estates: Evidence from Guangzhou. Urban Studies, 49(11), 2439-2457. 